\title{
KONTRIBUSI KECEPATAN DAN KESEIMBANGAN TERHADAP KEMAMPUAN TENDANGAN DOLLYO CHAGI ATLET PUTRA TAEKWONDO DOJANG TELADAN KOTA BENGKULU
}

\author{
Muslim Hidayat \\ email : muslimhidayat28@gmail.com \\ Universitas Bengkulu \\ Syafrial \\ Universitas Bengkulu \\ Tono Sugihartono \\ Universitas Bengkulu
}

\begin{abstract}
Abstrak
Penelitian ini bertujuan untuk mengetahui seberapa besar kontribusi kecepatan dan keseimbangan terhadap kemampuan tendangan dollyo chagi atlet putra taekwondo dojang teladan kota Bengkulu. Dalam penelitian ini ada 3 variabel yang digunakan yaitu kecepatan, keseimbangan dan tendangan dollyo chagi. Penelitian ini adalah penelitian korelasional dengan metode survei, sampel penelitian menggunakan total sampling kemudian pengambilan data penelitian dengan teknik tes. Analisis statistik yang digunakan adalah uji normalitas, homogenitas, kontribusi dan uji hipotesis. Hasil penelitian kecepatan memiliki hubungan positif dengan kemampuan dollyo chagi dengan $r_{\text {hitung }}=0,90>r_{\text {tabel }}=0,361$ dan memberi kontribusi sebesar $82 \%$, keseimbangan memiliki kontribusi positif dengan kemampuan tendangan dollyo chagi dengan $r_{\text {hitung }}=0,85>r_{\text {tabel }}=0,361$ dan memberi kontribusi sebesar $73 \%$. Kecepatan dan keseimbangan secara bersama-sama memiliki kontribusi yang positif dengan kemampuan tendangan dollyo chagi pada atlet putra taekwondo Dojang Teladan Kota Bengkulu dengan $r_{\text {hitung }}=0,91>r_{\text {tabel }}=0,361$ dan memberikan kontribusi sebesar $82 \%$. Dengan demikian maka dapat disimpulkan bahwa kecepatan dan keseimbangan secara bersama-sama memiliki kontribusi positif dengan kemampuan tendangan dollyo chagi.
\end{abstract}

Kata kunci: kecepatan, keseimbangan, tendangan Dollyo Chagi

\begin{abstract}
This study aims to determine how much the contribution of speed and balance to the dollyo chagi kick ability of male taekwondo athletes is exemplary in the city of Bengkulu. In this study there were 3 variables used, namely speed, balance and kick dollyo chagi. This study is a correlational study with survey methods, the study sample used total sampling and then took research data with test techniques. The statistical analysis used is the test for normality, homogeneity, contribution and hypothesis testing. The results of velocity research have a positive relationship with the ability of dollyo chagi with $r_{\text {count }}=0,90>r_{\text {table }}=0.361$ and contribute $82 \%$, balance has a positive contribution to our dollyo chagi kick ability with $r_{\text {count }}=$
\end{abstract}


$0,85>r_{\text {table }}=0.361$ and contribute $73 \%$. Speed and balance together have a positive contribution to the dollyo chagi kicking ability in taekwondo Dojang Teladan male athletes in Bengkulu City with $r_{\text {count }}=0,91>r_{\text {table }}=0.361$ and contribute $82 \%$. Thus it can be concluded that speed and balance together have a positive contribution to dollyo chagi's kicking ability.

Keywords: Speed, Balance, Dollyo Chagi Kick

\section{PENDAHULUAN}

Taekwondo adalah seni beladiri yang menggunakan banyak teknik, baik pukulan, tangkisan, dan tendangan.Teknik tendangan sangat lebih sangat dominan dalam seni beladiri taekwondo, bahkan harus diakui bahwa taekwondo sangat dikenal karena kelebihanya dalam teknik tendangan. Di dalam cabang olahraga beladiri taekwondo ada dua jenis cabang yang sering diperlombakan yaitu kyorugi (bertarung) dan poomsae (gerakan jurus). Salah satu teknik tendangan yang sangat sering digunakan saat bertanding kyorugi adalah teknik tendangan dollyo chagi. Tendangan dollyo chagi pada dasarnya menggunakan bantalan kaki namun sering pula menggunakan punggung kaki. Dalam pertandingan olahraga taekwondo untuk memperoleh poin, seorang taekwondoin (atlet) harus mampu memiliki kemampuan menendang yang baik yaitu menggunakan teknik serangan yang benar, bertenaga, serta faktor yang paling penting adalah kecepatan dan keseimbangan pada saat melakukan tendangan maupun bertahan. Kemampuan taekwondoin tergantung dari proses latihan yang dilaksanakan karena latihan adalah salah satu cara untuk meningkatkan kemampuan fungsi fisiologis dan psikologis. Latihan merupakan proses bekerja secara berulang-ulang dalam jangka waktu yang relatif panjang yang kemudian ditingkatkan secara bertahap berdasarkan kemampuan individual yang ditunjukkan pada pembentukan fungsi fisiologis dan psikologis untuk memenuhi tuntutan tugas tertentu. Dalam cabang olahraga taekwondo, kecepatan merupakan komponen fisik yang esensial dan merupakan faktor penentu terutama saat taekwondoin berada dalam situasi pertandingan. Hal ini didasarkan pada tuntutan pertandingan olahraga taekwondo yang biasanya berlangsung secara dinamis dan cepat.

Di kota Bengkulu sendiri perkembangan cabang olahraga ini sangat berkembang pesat dibuktikan dengan banyak nya berdiri dojang (tempat latihan taekwondo) yang paling terkenal dojang (tempat latihan) di Bengkulu diantaranya Club Teladan, dojang Walikota, dojang Brimob, Unit Kegiatan Mahasiswa (UKM) UMB dan Unit Kegiatan Mahasiswa (UKM) Universitas Bengkulu. Berdasarkan observasi dan survey terhadap atlet putra taekwondo dojang Teladan kota Bengkulu, jelas terlihat kemampuan tendangan dollyo chagi yang meliputi kecepatan dan keseimbangan dalam melakukan tendangan sangat rendah, sehingga jika diaplikasikan pada pertandingan poin yang diperoleh akan sangat rendah dan jika kurang keseimbangan saat bertanding bisa dilakukan pemotongan nilai 1 (satu) poin jika atlet jatuh saat menendang maupun ditendang oleh lawan sehingga merugikan bagi atlet itu sendiri. Hal ini dibuktikan saat pertandingan ulang tahun dojang teladan Kota Bengkulu yang diadakan di Gedung Olahraga (GOR) Sekolah Olahraga (SKO) 
provinsi Bengkulu hanya menyumbang 3 medali dari 28 atlet yang dikirim bahkan juara umum didapatkan oleh Kabupaten Rejang Lebong padahal dojang teladan merupakan dojang tertua di provinsi Bengkulu. Dari pengamatan peneliti disebabkan masih jarangnya diterapkan variasi latihan yang meningkatkan kemampuan tendangan pada atlet, seperti lari sprint dan melatih keseimbangan atlet dan juga saat peneliti melakukan observasi dan melakukan wawancara ke pelatih taekwondo dojang teladan Kota Bengkulu pelatih menjelaskan "atlet putra lebih dominan ke bagian kyorugi (bertarung) sedangkan untuk atlet putri lebih tertarik mengikuti pomsae (seni/jurus)". Sedangan menurut Suryadi (2010:33) aturlah keseimbangan sebaik-baiknya, karena untuk melakukan tendangan yang cepat butuh keseimbangan yang baik dan untuk menjaga keseimbangan yang baik butuh kecepatan tendangan.

Menyikapi dari permasalahan yang sudah dijelaskan di atas, peneliti tertarik dan akan berusaha untuk mengetahui seberapa besar "Kontribusi Kecepatan dan Keseimbangan Terhadap Kemampuan Tendangan Dollyo chagi Atlet Putra Taekwondo Dojang Teladan Kota Bengkulu".

\section{METODE}

Jenis penelitian ini adalah penelitian Deskriptif korelasional, menurut Dian Pujianto, Bayu Insanistyo, (2003:54). Deskriptif korelasional adalah penelitian yang menggambarkan hubungan antara beberapa variabel. Deskriptif korelasional memungkinkan peneliti mengetahui dua variabel atau lebih berhubungan satu sama lain. Dalam penelitian ini terdapat 2 (dua) variabel yang akan dikaitkan, yakni variabel bebas dan variabel terikat. Adapun variabel bebas dalam penelitian ini adalah kecepatan dan keseimbangan sedangkan variabel terikatnya adalah kemampuan tendangan dollyo chagi atlet putra taekwondo. Menurut Sugiyono (2012:80) populasi adalah wilayah generalisasi yang terjadi atas obyek atau subjek yang mempunyai kuantitas dan karakteristik tertentu yang ditetapkan oleh peneliti untuk mempelajari dan ditarik kesimpulannya. Sedangkan populasi menurut Dian Pujianto, Bayu Insanistyo (2017:71) populasi adalah seluruh obyek penelitian yang akan diambil sampelnya. Adapun populasi dari penelitian ini adalah semua atlet putra dojang teladan Kota Bengkulu berjumlah 30 orang atlet yang sudah menguasai teknik dasar tendangan dollyo chagi. Menurut Sugiyono (2012: 81) menjelaskan bahwa sampel adalah bagian dari jumlah dan karakteristik yang memiliki oleh populasi tersebut. Bila populasi besar, dan peneliti tidak mungkin mempelajari semua yang ada pada populasi di karenakan keterbatasan dana, tenaga, dan waktu maka peneliti cukup mengambil dari jumlah populasi. Sedangkan menurut Dian Pujianto, Bayu Insanistyo (2017:72) sampel adalah perwakilan dari seluruh populasi yang ada, perwakilan ini telah dianggap mewakili populasi yang ada. Adapun sampel dalam penelitian ini adalah menggunakan metode sampling total dari populasi sebanyak 30 atlet putra, dimana atlet tersebut sudah mahir dalam menguasai tendangan dollyo chagi.

\section{HASIL DAN PEMBAHASAN}

Dari hasil perhitungan tes kecepatan yang dilakukan terhadap atlet putra dojang teladan kota Bengkulu didapat skor tercepat 1,41 dan skor terlama 4,41, berdasarkan data kelompok tersebut rata- 
rata hitung (mean) 3,04 dan simpangan baku 0,69. Distribusi kategori kecepatan atlet putra dojang teladan Kota Bengkulu dapat dilihat pada tabel berikut:

Tabel 1. Distribusi Frekuensi Hasil Tes Kecepatan

\begin{tabular}{c|c|c} 
Hasil Tes & $\begin{array}{l}\text { Frekuensi } \\
\text { Absolut }\end{array}$ & $\begin{array}{l}\text { Frekuensi } \\
\text { Relatif (\%) }\end{array}$ \\
\hline $1,41-1,91$ & 2 & 7 \\
\hline $1,92-2,41$ & 4 & 13 \\
\hline $2,42-2,91$ & 6 & 20 \\
\hline $2,92-3,41$ & 10 & 33 \\
\hline $3,42-3,91$ & 6 & 30 \\
\hline $3,92-4,41$ & 2 & 7 \\
\hline Jumlah & 30 & 100
\end{tabular}

Dari tabel 5 dapat disimpulkan bahwa dari 30 atlet putra dojang teladan kota Bengkulu sebanyak 2 atlet $(7 \%)$ memiliki kategori 1,41-1,91. 4 atlet (13\%) memiliki kategori nilai 1,92 -2,41 dan 6 atlet (20\%) memiliki kategori 2,42 - 2,91, dan 10 atlet (33\%) memiliki kategori nilai 2,92 3,41 dan 6 atlet (30\%) memiliki kategori nilai 3,42 - 3,91 dan 2 atlet (7\%) memiliki kategori nilai 3,92 - 4,41. Untuk lebih jelasnya lagi dapat dilihat pada grafik berikut :

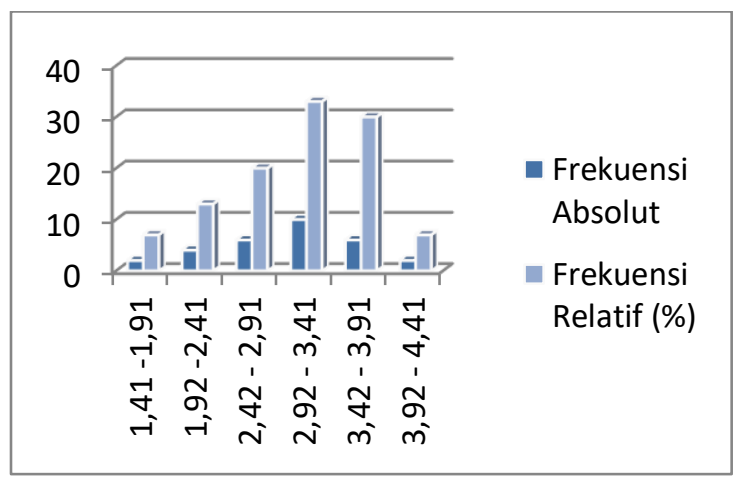

Gambar 1. Grafik Distribusi Tes Kecepatan Dari hasil pengukuran tes keseimbangan yang dilakukan terhadap atlet putra dojang teladan Kota Bengkulu didapat skor tertinggi 54,14 dan skor terendah 30,35. Berdasarkan data kelompok tersebut rata-rata hitung (mean) 43,70 dan simpangan baku 5,42. Distribusi kategori keseimbangan dapat dilihat pada tabel berikut:

Tabel 2. Distribusi Frekuensi Hasil Tes Keseimbangan

\begin{tabular}{c|c|c} 
Hasil Tes & $\begin{array}{l}\text { Frekuensi } \\
\text { Absolut }\end{array}$ & $\begin{array}{l}\text { Frekuensi } \\
\text { Relative (\%) }\end{array}$ \\
\hline $30,35-34,35$ & 2 & 7 \\
\hline $34,36-38,35$ & 2 & 7 \\
\hline $38,36-42,35$ & 7 & 23 \\
\hline $42,36-46,35$ & 12 & 40 \\
\hline $46,36-50,35$ & 3 & 10 \\
\hline $50,36-54,35$ & 4 & 13 \\
\hline Jumlah & 30 & 100
\end{tabular}

Dari data Tabel 6 dapat disimpulkan bahwa dari 30 atlet putra dojang teladan kota Bengkulu sebanyak 2 atlet (7\%) memiliki kategori nilai 30,35 - 34,35 dan 2 atlet (7\%) memiliki kategori nilai 34,36 38,35. 7 atlet (23\%) memiliki kategori nilai 38,36 - 42,35. 12 atlet (40\%) memiliki kategori nilai 42,36 - 46,35 dan 3 atlet (10\%) memiliki kategori 46,36 - 50,35. Sebanyak 4 atlet (13\%) memiliki kategori nilai 50,36 - 54,35. Untuk lebih jelasnya lagi dapat dilihat pada grafik berikut :

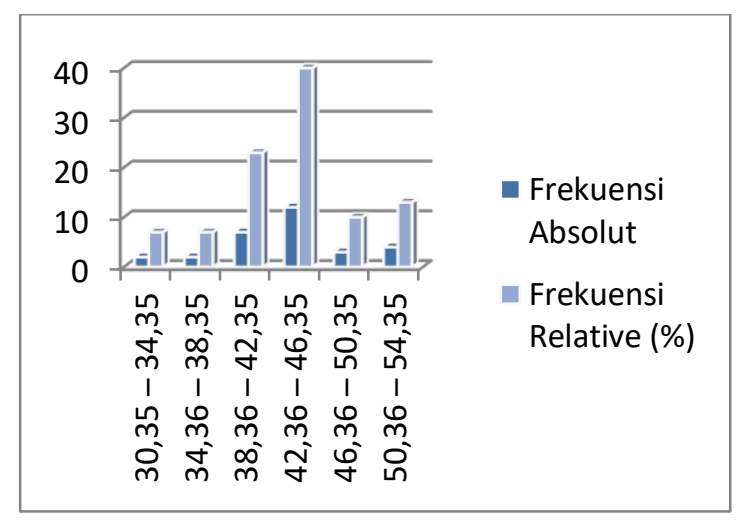


Gambar 2. Grafik Distribusi Hasil Tes Keseimbangan

Dari hasil pengukuran tes kemampuan dollyo chagi yang dilakukan terhadap atlet putra dojang teladan kota Bengkulu diperoleh skor tertinggi 30 dan skor terendah 18, berdasarkan data kelompok tersebut rata-rata hitung (mean) 24,43 dan simpangan baku 2,81. Distribusi kategori kemampuan dollyo chagi atlet putra dojang teladan kota Bengkulu dapat dilihat pada tabel berikut:

Tabel 3. Distribusi Frekuensi Hasil Tes Kemampuan Dollyo Chagi

Dari data tabel 7 dapat disimpulkan bahwa dari 30 atlet putra dojang teladan kota Bengkulu sebanyak 2 atlet (7\%) memiliki kategori nilai 18-20 dan sebanyak 4 atlet (17\%) memiliki kategori nilai 21-22. Sebanyak 10 atlet (27\%) memiliki kategori nilai 23-24 dan 10 atlet (33\%) memiliki kategori nilai 25-26 dan sebanyak 2 atlet (7\%) memiliki kategori nilai 27-28 dan sebanyak 3 atlet(10\%) memiliki kategori nilai 29-30. Untuk lebih jelasnya lagi dapat dilihat pada grafik berikut :

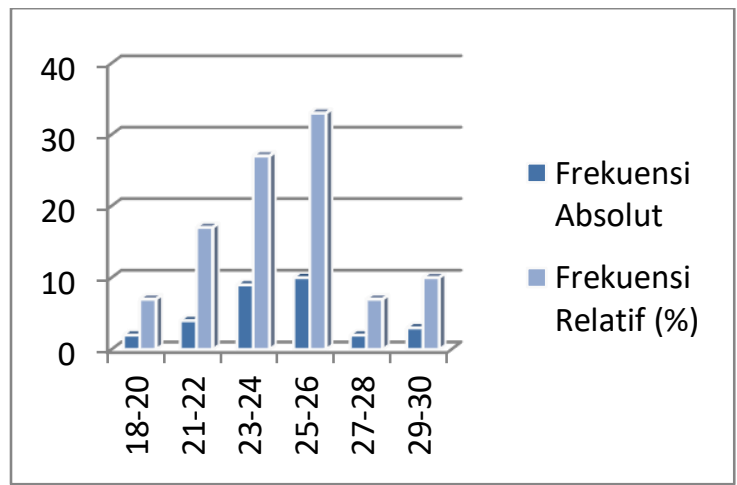

Gambar 3. Grafik Distribusi Tes Kemampuan Dollyo chagi

Hasil uji normalitas data dari setiap variabel adalah sebagai berikut untuk kontribusi kecepatan $\left(X_{1}\right)$ adalah $L_{\text {hitung }}=$
$0,037<L_{\text {tabel }}=0,161$ pada taraf signifikan $\alpha$ $=0,05$ dengan $n=30$. Sehingga terima $H_{0}$ atau dapat disimpulkan bahwa skor yang diperoleh dari Kontribusi kecepatan berdistribusi normal. Hasil pengujian normalitas untuk kontribusi keseimbangan $\left(X_{2}\right)$ adalah $L_{\text {hitung }}=0,079<L_{\text {tabel }}=0,161$ pada taraf signifikan $\alpha=0,05$ dengan $n=30$. Sehingga terima $\mathrm{H}_{0}$ atau dapat disimpulkan bahwa skor yang diperoleh dari Kontribusi keseimbangan berdistribusi normal. Hasil pengujian normalitas untuk kemampuan Dollyo chagi (Y) adalah L Litung $=0,122<$ $L_{\text {tabel }}=0,161$ pada taraf signifikan $\alpha=0,05$ dengan $n=30$. Sehingga terima $\mathrm{H}_{0}$ atau

\begin{tabular}{c|c|c} 
Hasil Tes & $\begin{array}{c}\text { Frekuensi } \\
\text { Absolut }\end{array}$ & $\begin{array}{c}\text { Frekuensi } \\
\text { Relatif (\%) }\end{array}$ \\
\hline $18-20$ & 2 & 7 \\
\hline $21-22$ & 4 & 17 \\
\hline $23-24$ & 9 & 27 \\
\hline $25-26$ & 10 & 33 \\
\hline $27-28$ & 2 & 7 \\
\hline $29-30$ & 3 & 10 \\
\hline Jumlah & 30 & 100
\end{tabular}

dapat disimpulkan bahwa skor yang diperoleh dari kemampuan Dollyo chagi berdistribusi normal.

Variabel dalam penelitian ini adalah kontribusi kecepatan $\left(X_{1}\right)$, kontribusi keseimbangan $\left(\mathrm{X}_{2}\right)$ dan kemampuan dollyo chagi $(\mathrm{Y})$. Hasil perhitungan varians dari kecepatan $\left(X_{1}\right)$ adalah 99,857 sedangkan varians keseimbangan $\left(X_{2}\right)$ adalah 221,344 dan kemampuan dollyo chagi $(Y)$ adalah 87,402

$$
\begin{aligned}
& \text { Fhitung }=\frac{\text { Varians Terbesar }}{\text { varians Terkecil }} \\
& F_{\text {hitung }}=\frac{221,344}{87,402}=2,532
\end{aligned}
$$

Dari perhitungan diatas didapat nilai $F_{\text {hitung }}=2,532$ sedangkan nilai $F_{\text {tabel }}$ taraf siginifikan $\alpha=0,05$ dengan $d b=(k-1)=2, d b$; 
$(n-1)=29$ dimana 2 sebagai pembilang dan 29 sebagai penyebut adalah sebesar 3,327. $F_{\text {hitung }}<F_{\text {tabel }}$ yaitu $2,532<3,327$ ini berarti tidak terdapat perbedaan dari masingmasing variabel atau harga variansnya Homogen.

Hipotesis pertama yang diajukan dalam penelitian ini adalah terdapat hubungan yang positif dan signifikan antara kontribusi kecepatan dengan kemampuan dollyo chagi. Berdasarkan analisis data didapat $r_{\text {hitung }}=0,90$ dan $t_{\text {hitung }}=11,43$. rhitung $_{\text {hing }}$ lebih besar dari pada $r_{\text {tabel }}$ dimana $r_{\text {hitung }}=$ $0,90>r_{\text {tabel }}=0,361$ berarti ada kontribusi yang positif antara kontribusi kecepatan dengan kemampuan dollyo chagi. Berdasarkan tabel interprestasi koefisien korelasi berari tingkat kontribusinya berada pada tingkat kontribusi yang kuat. Kontribusi kecepatan terhadap kemampuan dollyo chagi yaitu $\mathrm{K}=\mathrm{r}^{2} \times 100 \%=(0,90)^{2} \times$ $100 \%=82 \%$. Jadi dapat disimpulkan kontribusi kecepatan terhadap kemampuan dollyo chagi adalah sebesar $82 \%$. Untuk mengetahui kualitas keberartian regresi

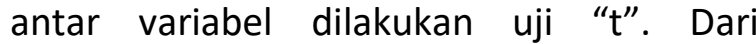
perhitungan didapatkan nilai $t_{\text {hitung }}=11,43$ dengan $\mathrm{n}=30$ sedangkan $t_{\text {tabel }}$ pada taraf siginifikan $\alpha=0,05$ diperoleh 2,75 yang lebih besar dari tabel sehingga dapat disimpulkan bahwa korelasi antara kontribusi kecepatan dengan kemampuan dollyo chagi adalah signifikan.

Hipotesis pertama yang diajukan dalam penelitian ini adalah terdapat hubungan yang positif dan signifikan antara kontribusi keseimbangan dengan kemampuan Dollyo chagi. Berdasarkan analisis data didapat $r_{y x_{1}}=0,85$ dan $t_{\text {htung }}=$ 8,76. $r_{\text {hitung }}$ lebih besar dari pada $r_{\text {tabel }}$ dimana $r_{\text {hitung }}=0,85>r_{\text {tabel }}=0,361$ berarti ada hubungan yang positif antara kontribusi keseimbangan terhadap kemampuan dollyo chagi. Berdasarkan tabel interprestasi koefisien korelasi berart tingkat hubungannya berada pada tingkat hubungan yang kuat. Kontribusi keseimbangan terhadap kemampuan dollyo chagi yaitu $K=r^{2} \times 100 \%=(0,85)^{2} \times 100 \%=$ 73\%. Jadi dapat disimpulkan kontribusi keseimbangan terhadap kemampuan dollyo chagi adalah sebesar $73 \%$. Untuk mengetahui kualitas keberartian regresi antar variabel dilakukan $u j i$ " $t$ ". Dari perhitungan didapatkan nilai $t_{\text {hitung }}=8,76$ dengan $\mathrm{n}=30$ sedangkan tabel pada taraf siginifikan $\alpha=0,05$ diperoleh 2,75 yang lebih besar dari $t_{\text {tabel }}$ sehingga dapat disimpulkan bahwa korelasi antara kontribusi keseimbangan dengan kemampuan dollyo chagi adalah signifikan.

Hipotesis ketiga yang diajukan dalam penelitian ini adalah terdapat hubungan yang positif dan signifikan antara kontribusi kecepatan, kontribusi keseimbangan dengan kemampuan dollyo chagi. Pengujian Hipotesis ketiga ini menggunakan korelasi ganda. $r_{\text {htung }}$ lebih besar daripada $r_{\text {tabel }}$ dimana $r_{\text {htung }}=0,91>r_{\text {tabel }}=0,361$ berarti ada hubungan yang positif antara kontribusi kecepatan dan kontribusi keseimbangan secara bersama-sama terhadap kemampuan dollyo chagi. Berdasarkan tabel interprestasi koefisien korelasi berari tingkat hubungannya berada pada tingkat hubungan yang kuat. Kontribusi keseimbangan terhadap kemampuan dollyo chagi yaitu $\mathrm{K}=\mathrm{r}^{2} \mathrm{x}$ $100 \%=(0,91)^{2} \times 100 \%=82 \%$. Jadi dapat disimpulkan kontribusi kecepatan dan keseimbangan terhadap kemampuan dollyo chagi adalah sebesar $82 \%$. Untuk mengetahui kualitas keberartian regresi antara variabel dilakukan uji " $F$ ". Dari perhitungan didapatkan nilai $\mathrm{F}_{\text {tabel }}=3,32$ dengan $n=30$ pada taraf siginifikan $\alpha=0,05$ diperoleh nilai sebesar 40,31 yang lebih 
besar dari $F_{\text {tabel }}$ sehingga dapat disimpulkan bahwa korelasi antara kontribusi kecepatan dan keseimbangan secara bersama-sama terhadap kemampuan dollyo chagi adalah signigfikan.

Berdasarkan hipotesis di atas dapat disimpulkan bahwa terdapat kontribusi yang positif antara variabel-variabel bebas yaitu kontribusi kecepatan $\left(X_{1}\right)$ dan kontribusi keseimbangan $\left(\mathrm{X}_{2}\right)$ terhadap variabel terikatnya yaitu kemampuan dollyo chagi (Y). Selanjutnya untuk lebih jelas dapat dilihat pada tabel hasil rangkuman hipotesis berikut ini.

Tabel 4. Rangkuman Hipotesis $\mathrm{X}_{1}, \mathrm{X}_{2}$ dan $\mathrm{Y}$

\begin{tabular}{l|c|c|c} 
Variabel & r hitung & Kontribusi & $\begin{array}{c}\text { Variabel } \\
\text { lain }\end{array}$ \\
\hline $\mathrm{X}_{1}$ dan $\mathrm{Y}$ & 0,90 & $82 \%$ & $18 \%$ \\
\hline $\mathrm{X}_{2}$ dan $\mathrm{Y}$ & 0,85 & $73 \%$ & $27 \%$ \\
\hline $\mathrm{X}_{1}, \mathrm{X}_{2}$ dan & 0,91 & $82 \%$ & $18 \%$ \\
$\mathrm{Y}$ & & &
\end{tabular}

Berdasarkan tabel 4 hipotesis di atas juga dapat disimpulkan bahwa terdapat kontribusi yang positif antara variabelvariabel bebas yaitu kontribusi kecepatan $\left(X_{1}\right)$ dan kontribusi keseimbangan $\left(X_{2}\right)$ terhadap variabel terikatnya yaitu kemampuan dollyo chagi $(\mathrm{Y})$.

Selanjutnya lebih jelas dapat dilihat pada diagram kontribusi variabel berikut ini :

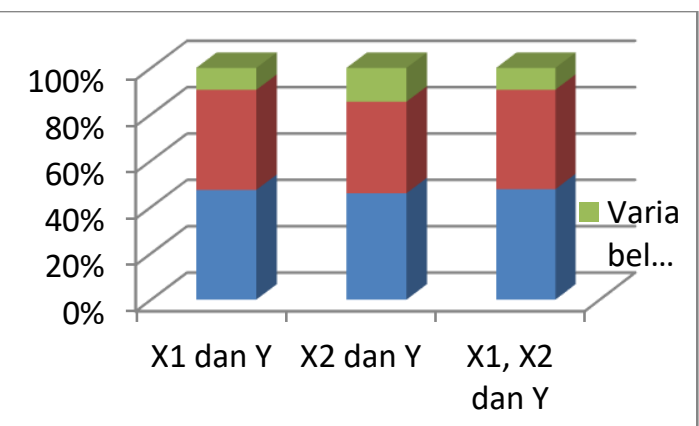

Gambar 4. Diagram Distribusi Variabel

\section{PEMBAHASAN}

Berdasarkan hasil penelitian yang dikemukakan dan dari hasil pengujian hipotesis ternyata (Ha) diterima kebenarannya. Ada kontribusi yang sigfinikan antara kecepatan dan keseimbangan terhadap kemampuan tendangan dollyo chagi. Pengujian hipotesis antara kontribusi kecepatan $\left(\mathrm{X}_{1}\right)$ dengan kemampuan tendangan dollyo chagi (Y). Kecepatan adalah kemampuan seseorang untuk melakukan gerakan dengan waktu yang sangat singkat agar mencapai hasil yang sebaik mungkin. Kecepatan merupakan unsur gerak dasar yang berguna untuk mencapai prestasi yang maksimal. Berdasarkan hasil analisis yang di kemukakan dari hasil pengujian hipotesis ternyata diterima (Ha) ada kontribusi yang positif dan signifikan antara keseimbangan terhadap kemampuan tendangan dollyo chagi dalam olahraga taewkondo. Dengan demikian seorang Taekwondoin harus memiliki keseimbangan yang baik sehingga menghasilkan keterampilan tendangan dollyo chagi yang baik pula.

Syafruddin (2011:87) mengemukakan bahwa secara fisiologis kecepatan diartikan sebagai kemampuan yang berdasarkan kelentukan (fleksibilitas), proses sistem persyaratan dan alat-alat otot untuk melakukan gerakan-gerakan dalam satu satuan waktu tertentu. Sedangkan secara fisikalis kecepatan dapat diartikan alat-alat untuk melakukan gerakan-gerakan dalam satu satuan waktu tertentu. Sedangkan secara fisikalis kecepatan dapat diartikan sebagai jarak dibagi waktu, dan hasil dari pengaruh kekuatan terhadap tubuh yang bergerak, dimana kekuatan dapat mempercepat gerakan tubuh. Berdasarkan hasil penelitian yang dikemukakan dan hasil pengujian hipotesis ternyata hipotesis yang 
diajukan diterima kebenarannya ada kontribusi yang positif dan signifikan antara kecepatan dan keseimbangan terhadap kemampuan tendangan dollyo chagi dan dapat disimpulkan bahwa semakin cepat dan seimbang maka semakin baik pula kemampuan tendangan dollyo chagi. Tendangan dollyo chagi membutuhkan kecepatan dan keseimbangan untuk menghasilkan poin saat melakukan pertandingan.

\section{PENUTUP}

\section{SIMPULAN DAN SARAN}

Berdasarkan hasil penelitian dan pembahasan yang telah di sampaikan dengan menggunakan uji normalitas data, uji homogenitas, uji hipotesis dan uji korelasi ganda, dapat disimpulkan yaitu : Terdapat kontribusi yang positif dan signifikan kecepatan dengan kemampuan dollyo chagi, dengan kontribusi sebesar 82\%. Hal ini berarti bahwa kecepatan berpengaruh sangat kuat terhadap kemampuan dollyo chagi. Terdapat kontribusi yang positif dan signifikan keseimbangan dengan kemampuan dollyo chagi, dengan kontribusi sebesar $73 \%$. Hal ini berarti bahwa keseimbangan berpengaruh sangat kuat terhadap kemampuan dollyo chagi. Terdapat kontribusi yang positif dan signifikan kontribusi kecepatan dan keseimbangan dengan kemampuan dollyo chagi, dengan kontribusi sebesar $82 \%$. Hal ini berarti kecepatan dan keseimbangan berpengaruh kuat terhadap kemampuan dollyo chagi.

Berdasarkan pada kesimpulan diatas, maka penulis dapat memberikan saran-saran yang dapat membantu mengatasi masalah kemampuan tendangan dollyo chagi yang ditemui pada olahraga taekwondo yaitu : Bagi Pelatih disarankan untuk mengajarkan secara intensif faktor yang mempengaruhi hasil keterampilan teknik dalam cabang olahraga taekwondo yaitu kecepatan dan keseimbangan secara berkelanjutan. Bagi atlet disarankan agar memahami teknik dan taktik dalam cabang olahraga taekwondo serta berlatih terus menerus secara sistematis dan berkesinambungan tentang besarnya pengaruh yang dominan terhadap keberhasilan teknik keterampilan yaitu kecepatan dan keseimbangan. Bagi Peneliti yang ingin melanjutkan penelitian ini agar dapat menjadikan penelitian ini sebagai bahan informasi dan meneliti dengan jumlah populasi dan sampel yang lebih besar serta di daerah yang berbeda.

\section{DAFTAR PUSTAKA}

Aip Syarifuddin.1992. Atletik. Jakarta : Departemen Pendidikan dan Kebudayaan.

Ariansyah. 2017. Hubungan Keseimbangan dan Keseimbangan Otot Tungkai Terhadap Kemampuan Tendangan Dolly Chagi pada Atlet UKM (Unit Kegiatan Mahasiswa) Taekwondo. [skripsi]. Bengkulu. (ID). Universitas Bengkulu.

Asyari A.F. 2017. Hubungan Antara Panjang Tungkai Dan Keseimbangan Tungkai Dengan Hasil Tendangan Dollyo Chagi Pada Atlet Putra Sabuk Kuning Usia 18 Tahun Taekwondo Thjc Bandar Lampung. [skripsi]. Lampung. (ID). Universitas Bandar Lampung.

Dofi B.A. 2004. Seni Beladiri Taekwondo. Bekasi : PT Golgen Terayon Press.

Fenanlampir. A. dan Faruq. M.M. 2015. Tes dan Pengukuran Dalam Olahraga. Yogyakarta : CV Andi Offset. 
Ghulam N. F. 2018. Keterampilan Tendangan Dollyo Chagi Atlet Taekwondo. Bekasi : PT Golden Terayon press.

Gunawan. G. A. 2007. Beladiri. Yogyakarta : PT Pustaka Insan Madani.

Handoyo. A. 2010. Lari Jarak Pendek. Jakarta : Nobel Edumedia.

Haryanta. A.T dan Sujatmiko. E. 2012. Kamus Pendidikan Jasmani, Olahraga dan Kesehatan. Surakarta : Aksara Sinergi Media.

Pujianto.D dan Insanistyo B. 2013. Dasardasar Penelitian Pendidikan Jasmani.
Bengkulu : FKIP Universitas Bengkulu.

Singgih I. J. 2016. Pengaruh Latihan Karet Terhadap Kecepatan Tendangan Dollyo Chagi Siswa Ekstrakulikuler Taekwondo SMAN 1 Sleman. [skripsi]. Sleman.(ID). Universitas Negeri Yogyakarta.

Sugiyono. 2002. Metode Penelitian Administrasi.Bandung : Alfabeta

Suryadi. Y. 2003. Taekwondo Poomsae Tae Guek. Jakarta : PT Gramedia Pustaka Utama.

Widiastuti. 2017. Tes dan Pengukuran Olahraga. Jakarta : PT Raja Grafindo Persada. 